\title{
Vejamen de Alfonso de Batres para la Academia de 1638 (Manuscrito inédito). Estudio y edición crítica
}

\author{
Alfonso de Batres Vejamen in the 1638 Academy \\ (Unpublished Manuscript). Study and critical edition
}

Teresa Julio

Universitat de Vic

\section{RESUMEN}

Durante el mes de febrero de 1638 se celebraron en el palacio del Buen Retiro las fiestas de Carnestolendas. Entre las actividades programadas, se realizó una academia literaria en la que participaron poetas y cortesanos. De ella se conservan tres vejámenes: el de Alfonso de Batres, el de Antonio Coello y el de Francisco de Rojas Zorrilla.

En el presente artículo se analiza y edita críticamente el vejamen que Batres defendió ante sus majestades en el Salón Real del Retiro el 11 de febrero de 1638.

Palabras clave: vejamen, Batres, Academia, Siglo de Oro.

\section{ABSTRACT}

During February 1638 the Fiestas de Carnestolendas were celebrated at the Buen Retiro Palace, Madrid. Among the programmed activities, a literary gathering was held, open to numerous poets and courtiers. From this gathering three vejamenes have been preserved: those of Alfonso de Batres, Antonio Coello and Francisco de Rojas Zorrilla.

In this paper we analyze and annotate the vejamen that Batres read before His Majesties in the Royal Salon of the Retiro Palace on February 11, 1638.

Key words: Vejamen, Batres, Academy, Golden Age.

\section{JUSTIFICACIÓN}

Tal vez el lector actual se pregunte por qué interesa editar el manuscrito que Alfonso de Batres leyó ante la academia literaria celebrada en el Buen Retiro durante las Carnestolendas de 1638. Son diversas las razones que se podrían argüir, y la primera de ellas es sencillamente porque nunca ha teni- 
do la oportunidad de salir a la luz. En esa misma academia, sin edición completa de momento, se leyeron tres vejámenes: el de Francisco de Rojas Zorrilla, el de Antonio Coello y el de Alfonso de Batres. Los dos primeros han sido reproducidos en revistas o libros; en cambio, el de Batres ha quedado siempre relegado al olvido. El de Rojas fue trascrito por M. Serrano y Sanz, a partir del Mss. 12270 de la Biblioteca Nacional de España, y publicado como apéndice en la edición de El diablo cojuelo de Luis Vélez de Guevara, que preparó Bonilla y San Martín, bajo el título erróneo de: Vejamen leído por don Francisco de Rojas y Zorrilla en la academia que se celebró a 21 de febrero de 1637 en el Buen Retiro. La edición anotada del vejamen de Rojas la realicé yo misma, a partir del manuscrito de la Biblioteca Nacional de Portugal y del cotejo de otros textos, para la Revista de Literatura (Julio, 2007). Por su parte, el vejamen de Coello fue publicado por Paz y Melia en 1968.

La segunda razón: independientemente del valor literario, todo vejamen es potencialmente interesante, porque aporta información muy concreta sobre la vida cotidiana de sus protagonistas. A través de las burlas y de las chanzas obtenemos datos sobre:

(a) el aspecto físico de los vejaminados, por ejemplo, la calvicie de Francisco de Rojas, la suciedad de Antonio Coello, la nariz aguileña de Juan Vélez, los pies grandes de Gaspar de Bonifaz, las dificultades articulatorias de Francisco de Rioja, la sobrepanza de Diego de Covarrubias..., e incluso en algunos textos, hasta se ha dado cabida a la muletilla del Conde-Duque, recordando los graves ataques de gota que aquejaban al valido;

(b) las bromas que se gastaban en la época a propósito de la tacañería de Calero, la afición al juego de Pedro Méndez, las caídas de los regidores o la conversión de las damas de palacio en mondongas;

(c) los sobrenombres con que popularmente se conocía a los concurrentes de los certámenes literarios: Cuellecito (al poeta y, algunos años más tarde, ministro don Antonio Coello), Zapatilla (al honorable capitán de la guardia real don Francisco Zapata), Asprilla (al ilustre secretario del Conde-Duque don Francisco Gómez de Asperilla o Lasperilla); Zapatón (al noble caballerizo del rey y toreador de excepción don Gaspar de Bonifaz), etc.;

(d) las costumbres que hoy se han perdido: comer mondongo los sábados, echar las damas huevos de olor durante las carnestolendas, entre otras;

(e) los entretenimientos más frecuentes: mascaradas, torneos, palos ensebados, correr lanzas o jugar alcancías;

En suma, un vejamen ofrece un retrato de los personajes y de los hábitos que imperaban en la corte y, desde ese punto de vista, es una fuente más de información que nos aproxima de una manera distendida a la España de Velázquez y nos acerca a sus protagonistas, al tiempo nos que permite desentrañar el significado de algunas alusiones que aparecen en comedias, textos en prosa o poemas satíricos o burlescos al sacar a flote la cotidianidad compar- 
tida por los contemporáneos y, en ocasiones, perdida por carecer de la seriedad o gravedad que se requiere para pasar por el tamiz de la historiografía.

Con la edición del vejamen de Batres acercamos al lector un texto que se enmarca en los trabajos sobre academias y vejámenes estudiados y publicados por Romera Navarro (1941), King (1963), José Sánchez (1961), Carrasco Urgoiti (1965), Bergman (1975), Brown (1993), Egido (1984a, 1984b, 1990), Vicente Sánchez (2004) y Madroñal (2005, 2006), entre otros.

\section{DAtos BIOGRÁFICOS Y BIBLIOGRÁFICOS}

Son pocas las noticias que tenemos sobre la vida de Alfonso de Batres, y algunas de ellas son tan imprecisas como, por ejemplo, su propio nombre, trascrito en ocasiones como Alfonso o como Alonso. Justamente, sobre esa confusión, que ya se daba en vida del poeta, bromeó Rojas en su vejamen de la Academia de 1637:

Unos le llamaban señor Batres; otros, por lisonja, le llamaban señor don Alonso, pero viendo él que por añadirle un don le quitaban el de la efe, que aun no lo pudo conseguir el de la mano horadada, dijo a uno de los que le hacían donado de esta manera:

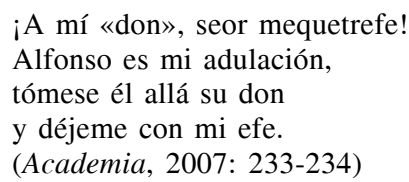

Y en la de 1638:

¿Sabe V. m. de qué me espanto yo? - le dije—, que sufra Madrid cosas en el primero que aún no se pudieran sufrir en el segundo. La una, que se llame Batres y, la dos, que se llame Alfonso, y cierto que, cuando muy niño, le conocí «Alonsico», después «Alonsillo»y, ya jovenete, «Alonso»y, mucho antes que se nos metiese a ser secretario, nos metió la efe por el ojo de una aguja, con tanto extremo que todas las alhajas que tiene en su casa tienen efe: en verano no pone en el estrado estera, sino alfombra; lo que ciñe no es espada, sino alfanje; los libros en que lee son el alfabeto y Alfarache; con quien comunica sus secretos es con el maestro Alfaro; si está acatarrado, no come caramelos, sino alfeñique; si compra colación, come alfónsigos y, si en palacio pretende por la guerra, es ser alférez. (Rojas, 2007: 313).

Los primeros datos biográficos nos llegaron de la mano de Juan Pérez Montalbán, que lo incluyó en el «Índice de los ingenios de Madrid», en su Para todos, y al que calificó de «ingenioso y galante poeta»; y nos dice que «escribió en octavas un Panegírico al señor don Manuel Pimentel, La fábula de Adonis y Venus en una silva, unas Rimas varias de versos heroicos y burlescos a diversos asuntos; y una comedia que se intitula, Venganzas hay si hay 
injurias, y todo con notable espíritu y aceptación» (1632: 340v $)^{1}$. Álvarez Baena también lo incorporó en su Hijos de Madrid, y, además de repetir parte de la información de Montalbán, añade que fue «criado de don Rodrigo Ponce de León, duque de Arcos, virrey de Nápoles» y que «vivía el año de 1635, en que hizo cuatro Décimas a la muerte de Lope de Vega; y en el de 39 una Silva a la del doctor Juan Pérez de Montalbán» (1789: 46). Pocos datos más aporta La Barrera y Leirado, que matiza la afirmación de Montalbán sobre la ingeniosidad y galantería del madrileño Batres con un «aunque no adornado de conocimientos eruditos» - lo que se trasluce en sus escritos donde se aprecia una pluma no muy afilada, no siempre a la altura de otros poetas cortesanos-, y añade que murió en la ciudad napolitana cuando estaba al servicio de Ponce de León (1968). Ese dato nos permite situar su muerte entre el 11 de febrero de 1646 y 26 de enero 1648, época en que su señor, el IV duque de Arcos, fue virrey de la ciudad napolitana ${ }^{2}$. No se sostiene, pues, la afirmación de La Barrera de que Batres formara parte de la Academia poética de Madrid de 1649, dato que el erudito madrileño concluye a partir de la fecha que tradicionalmente se dio al vejamen de don Jerónimo de Cáncer, «siendo secretario de ella». Estudios posteriores han puesto en entredicho la fecha de dicho vejamen, entre ellos, especialmente el de González Maya (2006), que finalmente lo sitúa entre 1644 y 1647. Si tenemos en cuenta que Batres está presente durante la lectura del vejamen y que en febrero de 1646 marcha a Nápoles, podemos ajustar un poco más la fecha de González Maya y datar el vejamen de Cáncer en alguna academia madrileña celebrada entre 1644 y muy a comienzos de 1646 .

Además de las obras señaladas más arriba, hay que añadir un par de escritos fúnebres: una composición en La pompa funeral. Honras y exequias en la muerte de la Alta y Católica señora doña Isabel de Borbón (1645) y un soneto, aparecido en las Exequias reales que Felipe el Grande, cuarto de este nombre, rey de las dos Españas, mandó hacer en San Felipe de Madrid a los soldados que murieron en la batalla de Lérida (1644).

También tenemos constancia de su participación en las academias literarias de 1637 y 1638 que se celebraron en el Buen Retiro y de las que fue secretario. En la primera, como poeta, obtuvo un tercer premio con la glosa que encabeza la academia y dos primeros premios, con un romance y un epigrama; y, como vejador, se llevó el primer premio, y Rojas, que hizo las veces de fiscal, el segundo. Del certamen literario de 1638 solo nos queda su vejamen. No obstante, no se descarta que actuara también como poeta y no

${ }^{1}$ Sobre la producción literaria de Batres podrá consultarse Julio, Teresa, «Obra literaria de Alfonso de Batres: recopilación poética y otros escritos», Boletín de la Real Academia Española, en prensa.

${ }^{2}$ Acerca de la estancia en Nápoles de Rodrigo Ponce de León como virrey, vid. Raneo (1853: 524-525) y Saavedra (2007: 29). 
nos hayan llegado sus composiciones, pues el manuscrito lisboeta es incompleto y, además, en las academias solo se transcribían las composiciones premiadas.

\section{El VEJAMEN EN SU CONTEXTO}

El vejamen de Batres, junto con el de Rojas y Coello - y presumiblemente, con el de Antonio Hurtado de Mendoza-, se leyó el 11 de febrero de 1638 en el Salón de Reinos del Palacio del Buen Retiro, ostentoso espacio destinado a las representaciones teatrales (antes de la creación del Coliseo en 1640), a los encuentros literarios y a la recepción de embajadores extranjeros, fácilmente impresionables a juicio de Olivares. En dicho certamen participaron los asiduos poetas de la corte, que compusieron sus escritos ajustándose a los asuntos propuestos, como era de rigor: Antonio Coello, Francisco de Rojas Zorrilla, Pedro Méndez, Francisco de Cabreros, Román Montero, Jerónimo de Cáncer, Luis de Belmonte, Antonio de Solís, Gaspar Dávila, Luis Vélez de Guevara, Luis Quiñones de Benavente, Antonio Hurtado de Mendoza, y quizás algunos más, intervinieron en él. En esta ocasión, el presidente fue, como sostiene Bergman (1975), Luis Vélez de Guevara y el secretario, Alfonso de Batres, al igual que en la academia burlesca del año anterior (Julio, 2007: 303). El tribunal que falló los premios estuvo compuesto por don Francisco de Borja y Aragón, Príncipe de Esquilache; don Luis de Haro, sobrino del Conde-Duque y futuro valido; don Francisco de Rioja, bibliotecario de Felipe IV y cronista de Castilla; don Francisco López de Calatayud, teniente contador del monarca; don Rodrigo Pacheco Ossorio, marqués de Cerralbo; don García de Avellaneda y Haro, conde de Castrillo, y el marqués Virgilio Malvezzi, reputado panegirista de Olivares.

Este certamen, justa o academia de 1638 —nombres con que se cita indistintamente este encuentro literario en el manuscrito de Lisboa- forma parte del conjunto de entretenimientos que se programaron para celebrar las Carnestolendas, que tradicionalmente se festejaban en el Palacio del Buen Retiro desde que se inaugurara en diciembre de 1633. Durante el viernes 5 de febrero y el martes 16 de 1638 se corrieron lanzas, sortijas y estafermos, se celebraron corridas de toros y mascaradas, se representaron comedias y se ejecutaron toda suerte de entretenimientos para regocijo de la familia real y de la camarilla de secretarios, nobles y aristócratas que la rodeaba, bufones, poetas, comediantes o invitados de alcurnia, como la duquesa de Chevreuse, Marie de Rohan-Montbazon, que unos meses antes había escapado de Francia y se hallaba de paso por España de camino a la corte inglesa ${ }^{3}$.

\footnotetext{
${ }^{3}$ Para la figura de la duquesa de Chevreuse, vid. Julio (2007: 300, n. 3).
} 
La academia de 1638 nació a la sombra de la Academia burlesca que se había celebrado el año anterior. En la mente de todos estaban las espléndidas fiestas con que Felipe IV recibió el nombramiento de Fernando III de Hungría como Rey de Romanos y la llegada a España de la princesa de Carignan, María de Borbón ${ }^{4}$. Unas celebraciones espectaculares en las que el lujo y el despilfarro fueron dominantes. Hubo entonces al igual que en las de ahora, entretenimientos cortesanos, meriendas, toros, espectáculos y un encuentro literario: una academia burlesca. A diferencia de ésta, la academia del 38 no colmó las expectativas que se había puesto en ella: al parecer, el ingenio y el buen gusto que habían reinado el año anterior se ausentaron en ocasiones y algunas creaciones literarias rayaron el mal gusto. Así el propio Rojas se llevó un primer premio, a pesar de que el jurado reconoció lo inapropiado del tono de su composición: «No se leyó en la academia este asunto porque pareció a los jueces malsonante; no obstante, que se me premió en primer lugar» (fol. 95v). En la Mojiganga de la boda, que se representó tras el encuentro literario, Santa Cruz alaba el certamen en general: «Mejor cosa que el certamen / en toda mi vida vi», al tiempo que Inés María puntualiza en su conversación con Moncada:

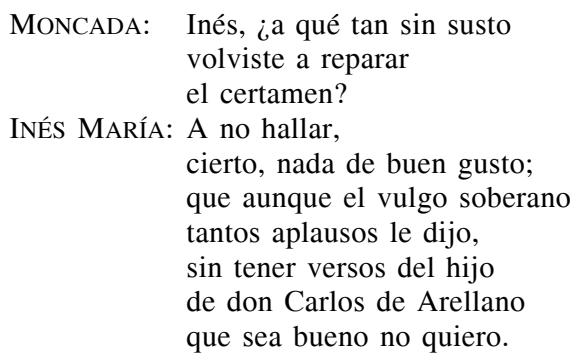

Esos testimonios evidencian que el encuentro literario no estuvo a la altura del que se realizó el año anterior y que las burlas no fueron todo lo refinadas que se esperaba o no se entendieron como tales.

\section{CONTENido y ESTRUCTURA}

El vejamen de Batres para la academia de 1638 comienza de una manera muy similar al que defendió Coello ese mismo año y para la misma ocasión; en ambos se alude al tópico del sueño como una suerte de marco en que inscribir la historia que se va a contar, y tienen como protagonista a don Juan de Espina y sus instrumentos musicales. Gracias a la lira de don Juan, Batres

\footnotetext{
${ }^{4}$ Sobre estos personajes y las fiestas de 1637, consúltese la introducción a Academia (2007: 11-38).
} 
se siente inmerso en una especie de elevación espiritual que le permite ver más allá de la realidad inmediata y observa la frenética actividad del gabinete de Olivares, formado por una multitudinaria camarilla de secretarios ajetreada por los asuntos de Estado. Batres, entre burlas y veras, hace un repaso de los ministros del Conde-Duque señalando con ironía sus vicios y tachas, como corresponde a cualquier vejamen. Por el espejo mágico de Espina, convertido en una ventana abierta al mundo de la corte, desfila don Francisco Gómez de Asperilla, habilidoso en esconder memoriales; el laborioso don Jerónimo de Lezama, entregado en cuerpo y alma a su trabajo; el modesto don Antonio de Legarda, hábil en ocultar su juego; el joven don Pedro de Arteaga, dotado con una seriedad impropia de sus años; el indispensable don Antonio Carnero, mano derecha del valido; el atareado protonotario Jerónimo de Villanueva, con su renuencia al trato con mujeres; el virtuoso don Fernando de Contreras, con su «ojo preñado en falta»; el ministro hacedor de versos, marqués de Malpica; el atento y caballeroso conde de Puñonrostro, haciendo honor a su condición de regidor; el diligente Fernando Ramírez Fariñas, corregidor de Madrid; el enfrascado marqués del Carpio, obsesionado en reclutar gente para la guerra; el omnipresente conde del Castrillo, con su declarada inclinación por las espadas... Tras ese desfile de ministros, Batres se fija en otros sujetos presentes en la corte, como la poetisa doña Ana Caro, cuya condición femenina no le impide ser blanco de las críticas del madrileño, o don Bernardino de Ayala, conde de Villalba, encargado de organizar las fiestas de toros con más entrega y buena voluntad que medios. A través de este personaje se introducen en el discurso las actuaciones de los toreadores Gregorio Gallo y Juan Pacheco, que habían participado en las corridas celebradas el día anterior. A su vez, por el espejo aparece el secretario de Estado Diego Suárez discutiendo con el arquitecto Alonso Carbonel sobre la construcción de la ermita de San Antonio que este le ha encargado. El buen hacer del aposentador Pedro del Yermo, el griterío característico de Grimaldo Gutiérrez, los temores de Juan Mejía por los toros o la longeva edad de Vélez de Guevara sirven de hitos humorísticos en este muestrario de figuras cortesanas. Al final, cada uno de los vejaminados se dirige a sus quehaceres o escapa como puede de sus perseguidores. La obligada petición de perdón por las posibles ofensas cometidas pone fin al vejamen.

Como se puede observar, la intervención de Batres en la academia de 1638 no ofrece desde un punto de vista estructural o temático ninguna novedad. En la primera mitad del XVII las características que presentan los vejámenes literarios están bien definidas, como señaló Carrasco Urgoiti:

Lo que tienen en común los textos citados y otros vejámenes coetáneos es el orden de composición: alusión a la dificultad de la tarea con que se enfrenta el fiscal; hallazgo - generalmente en sueños- de un artificio fantástico y alegórico que encuadre el desfile de ingenios; serie de semblanzas jocosas, cada una de las cuales termina con una estrofilla burlona. La pieza suele concluir con una frase cortés de elogio a la asamblea cuyos miembros han soportado tanta chanza (1965: 102). 
Y en efecto, esa estructura ya presente en los primeros vejámenes del XVII se mantiene a lo largo de todo el siglo. El sueño como hilo conductor se convierte en un lugar común tan trillado que Antonio Coello afirma en su participación para esta misma academia:

Ello está de Dios que nos hemos de andar durmiendo los ministros de las academias, y es mucho que teniendo los poetas tanta sequedad de cerebro, nos deja Apolo nuestra humedad reservada para dormirnos (1964: 317).

El sueño como técnica aparece en numerosos vejámenes, como el de Pantaleón de la Ribera, publicado por Brown (1980), o el de Jerónimo de Cáncer, editado por González Maya (2006), por citar un par de casos muy conocidos, y por ello se ha llegado a hablar de los vejámenes de academias como escritos pertenecientes al género de los sueños. Es un recurso que da fácil entrada a la galería de personajes que desfilan por él y que son caracterizados o, mejor, caricaturizados a partir de dos o tres rasgos sobresalientes convertidos en algunas ocasiones ya en tópicos. De hecho, Batres recurre a bromas que podemos encontrar en los escritos de Rojas (2007), Coello (1964) o Juan de Orozco (1964), y a personalidades convertidas ya en personajes de vejámenes, como Vélez de Guevara, Gaspar de Bonifaz o el protonotario de Aragón, Jerónimo de Villanueva.

\section{NOTICIAS BIBLIOGRÁFICAS}

Del vejamen que compuso Alfonso de Batres para la academia literaria de las fiestas de 1638 sólo nos han llegado dos testimonios:

a) El manuscrito de la Biblioteca Nacional de Portugal, cod. 3788, F. R. 1394, ff. 53r-61v. En el mismo legajo se recoge además el texto en prosa del Juicio final de todos los poetas españoles vivos y muertos de Luis Vélez de Guevara, según Bergman (1975), el vejamen de Francisco de Rojas Zorrilla y el de Antonio Coello, algunos poemas sueltos que se compusieron a partir de los asuntos propuestos en el certamen, la comedia burlesca La muerte de Baldovinos de Jerónimo de Cáncer y la anónima Mojiganga de la boda, cuya representación corrió a cargo de diferentes personalidades de la nobleza. Este manuscrito es el que ha servido de base para la presente edición, ya que es que el que leyó Batres en febrero de 1638.

b) El siguiente testimonio que se ha localizado procede de la Biblioteca Nacional de España y lleva la signatura Mss. 18724/3. La ficha dice textualmente: «Vexamen en prosa que dio a varios poetas y secretarios del rey Felipe V» (sic). Ocupa los folios 1r-5v. Los folios 1r-3v corresponden al parlamento de Batres, después entre los folios $3 \mathrm{v}-5 \mathrm{v}$ se halla incrustado un fragmento de un vejamen de Hurtado de Mendoza, y tras 
él continúa el texto de Batres, que acaba en el fol. 5v. En el manuscrito madrileño falta parte del texto que aparece en el lisboeta y se añade el escrito de Hurtado de Mendoza que parece pertenecer también a la academia del 38. Por ser este muy extenso para ponerlo en nota como variante, lo reproduzco al final como apéndice.

\section{NOTAS A LA EDICIÓN}

Como se ha señalado, la presente edición sigue como texto base el manuscrito de la Biblioteca Nacional de Lisboa, al que se le ha actualizado la ortografía, puntuación y acentuación.

Si la palabra anotada únicamente lleva numeración arábiga, significa que la nota al pie es una variante del texto. Si lleva numeración y asterisco, nos encontramos ante un comentario, aclaración o información adicional. De este modo se pueden realizar diferentes niveles de lectura en función de los intereses del lector, que puede querer conocer únicamente variantes textuales o precisar de alguna aclaración o sentir curiosidad por algún personaje o término que surge en el texto.

En el texto de Hurtado de Mendoza que reproducimos en el apéndice solo aparecen notas con números arábigos puesto que no tenemos variantes textuales.

\section{VEJAMEN DE Alonso DE BATRES ${ }^{5}$}

Y si yo hubiera de echar la culpa al sueño, a la admirable lira ${ }^{6}$ de don Juan de Espina $^{* 7}$ lo atribuyera ${ }^{8}$, pues nada de cuanto vi ${ }^{9}$ fue sueño, sino una elevación reser-

\footnotetext{
${ }^{5}$ Vejamen de Alonso de Batres: Alfonso de Batres (BNE).

${ }^{6}$ sueño, a la admirable lira: sueño, al rarísimo instrumento se la echara. No digo bien, a la admirable maña (BNE).

${ }^{7}$ Juan de Espina: don Juan de Espina y Velasco (1563-1643), famoso coleccionista y erudito de la corte de los Austrias, fue conocido también por su afición a la música y a la nigromancia. A estos dos aspectos alude Batres a través de la lira y del espejo. A él se le atribuye la puesta en funcionamiento de un novedoso sistema musical: «Creó un nuevo y especulativo sistema de «música por distancias cortas» [...] con arreglo a ello mandó construir una serie de «instrumentos científicos y perfectos», lira, vihuela, guitarra, viola da gamba - modificando las longitudes de las cuerdas o las distancias de los trastes-, que dejó en herencia al rey» (Aracil, 1998: 167). A propósito de la habilidad musical de Espina, Francisco Valdés, músico de la Capilla Real, en su memorial a Felipe IV señala: «Yo he oído tañer la lira a don Juan de Espina y Velasco y según lo que yo entiendo y he visto y oído en otros es digno de eterna alabanza» (Aracil, 1998: 168). Ahora se entiende que Batres quede transportado por la lira y el buen hacer de don Juan. El mundo de la magia lo introduce el poeta madrileño a través del espejo mágico en que ve lo que sucede en palacio.

${ }^{8}$ lo atribuyera: se la atribuyera (BNE).

${ }^{9}$ nada de cuanto vi: nada de aquello (BNE).
} 
vada a la música y me lo dio a entender ${ }^{10}$ con un ejemplo y, asomándome al prodigioso $^{11}$ marco de un espejo que estaba como un vidro*12 de ver lo que pasaba por él, vi que estaban un buen rato*13 de secretarios diciendo ${ }^{14}$.

- Mañana hemos de tomar.

Y que el señor Conde-Duque decía:

- ¿Qué habéis de tomar mañana?

- Hemos de tomar mañana la mañana, señor*15.

- No habéis de tomar ni aun la mañana, que, aunque es una niñería madrugar en estos tiempos ${ }^{16}$, ha de ser como quien no quiere la cosa.

Quedose el secretario Asprilla*17, que es mañosísimo con un papel ${ }^{18}$, haciendo muchos papeles, y diciendo ${ }^{19}$ :

- Yo he menester irme a trabajar con tiempo porque ${ }^{20}$ tengo muchísimas consultas que esconder.

Y la verdad es que en esto pone grandísimo cuidado, tanto ${ }^{21}$ que si pudiera hacer que no las viera quien las ha de decretar, lo hiciera, pues luego pondrá «ojo» a la margen*22.

- No, señor, que dice que le puede leer lo que escribe. No quieran más de

${ }^{10}$ música y me lo dio a entender: música. Verdad fue todo, que a mí me lo dio a enten$\operatorname{der}(\mathrm{BNE})$.

11 y asomándome al prodigioso: pues haciéndome asomar al prodigioso (BNE).

12 vidro: Antiguamente, «vidrio».

${ }^{13}$ buen rato: «Se toma por mucha o gran cantidad de alguna cosa» (Aut.).

${ }^{14}$ por él vi, que estaba así un buen rato de secretarios diciendo: por él, sin erizárseme el cabello llegué, y díjome: «Aquí hallarás cuantos esperan la fiesta, y muchos que estando allá no hacen ausencia de ti». Y apenas empecé a dar en la novedad un paso cuando vi un buen rato de secretarios que estaban diciendo (BNE).

${ }^{15}$ Hemos de tomar mañana la mañana, señor: La mañana, señor (BNE). Tomar la mañana: Madrugar. «Tras esto, despidiéndose los unos de los otros, cada uno con su huésped, se resolvieron, al partir, en que tomasen un poco la mañana, por causa de los excesivos calores que en aquel tiempo hacía.» (Fernández de Avellaneda, 2005: 66).

16 en estos tiempos: en este tiempo (BNE).

${ }^{17}$ el secretario Asprilla: Asprilla (BNE). Asprilla es el apodo con que se conoce burlonamente a Francisco Gómez de Asperilla o de Lasprilla, secretario del marqués de Velada y del Conde-Duque de Olivares, quien en la década de 1620 le encargó los asuntos de diversos consejos y la correspondencia con los ministros residentes en la corte. Posiblemente su carácter áspero y el parecido fonético del apellido facilitó ese juego lingüístico al que alude también Antonio Hurtado de Mendoza: «Pues del blando y dulce Asprilla, / la pluma, como es notorio, / es el mártir sin mancilla, / sea como de Sevilla / asistente de escritorio» (1947: 242).

${ }^{18}$ que es mañosísimo con un papel: con un papel (BNE).

19 diciendo: dijo (BNE).

${ }^{20}$ Yo he menester irme a trabajar con tiempo porque: Ahora bien, yo me voy a trabajar, porque (BNE).

${ }^{21}$ tanto: y tanto (BNE).

22 «ojo» a la margen: «Frase que se usa para explicar que se ponga advertencia en alguna cosa» (Aut.). 
que al secretario Lezama*23 le ha hecho desguarnecer*24 un vestido de terciopelo, porque se le antojó que pestañeaba mucho al raso*25. La verdad es que al tal Lezama ${ }^{26}$ no le ha estado muy mal porque ya trabaja como un descosido. Esto le pareció desgarro*27 a la modestia del secretario Legarda*28, y se fue a entretener hacia el corredor como jugador de pelota, con raqueta por no hacer ruido y por que no lo sienta el conde, mi señor, por debajo de la cuer$\mathrm{da}^{* 29}$. Pedro de Artiaga*30, con una mesura*31 que es vergüenza, se puso a trabajar, y cierto que es lástima que este Pedro no sea el mozo vergonzoso que trujo el diablo a palacio*32. Volviose el secretario Asprilla a su antiguo tema y a esconder memoriales del mismo que se los estaba dando ${ }^{33}$.

- Extraña prolijidad — dijo don Juan de Espina-, pero todo ${ }^{34}$ se le puede sufrir*35 porque es limpio.

- Yo no sé si es limpio o no, lo que sé es que le he visto echar en la bolsa más de cuatro trabajos ajenos, pero da muy buena cuenta de ellos, pues encargándole un pretendiente que no se le quedasen olvidados sus papeles, respondió ${ }^{* 36}$ :

${ }^{23}$ Lezama: don Jerónimo de Lezama (BNE). Lezama, caballero del hábito de Santiago, entró a formar parte de la cuadrilla de funcionarios del Conde-Duque en la década de 1630 y trabajó estrechamente con Antonio Carnero, indispensable secretario de Olivares. Estuvo casado con su prima, doña María de Lezama, y fue secretario del Consejo de Guerra. Murió a mediados de 1650. (Hidalguía, 1980: 705).

${ }^{24}$ desguarnecer: Quitarle los adornos a una prenda.

${ }^{25}$ pestañeaba mucho al raso: pestañeaba el raso (BNE). Aquí el término «pestaña» se ha de entender como «Cualquier adorno angosto que ponen al canto de algunas telas u vestidos, de flueco, encaje o cosa semejante, que sobresale algo» (Aut.). El significado sería que al secretario le han hecho descoser los adornos del vestido de terciopelo porque adornaban en exceso. Eso le permite el juego lingüístico de «trabajar como un descosido» que aparece a continuación para referirse al celo que ponía en su profesión.

${ }^{26}$ Lezama: don Jerónimo (BNE).

${ }^{27}$ desgarro: Doble acepción del término; por un lado, «rotura», siguiendo con la broma del traje desguarnecido y descosido; por otro, «desvergüenza, descaro».

${ }^{28}$ Antonio de Legarda fue secretario de Felipe IV desde 1623. (Escudero, 1976: 707).

${ }^{29}$ por debajo de cuerda: «Frase adverbial que expresa el modo de hacer alguna cosa por medios reservados y ocultos, para lograr con más seguridad el fin que se desea. Es alusión a cierta ley del juego de pelota, en que se ha de jugar siempre por encima de la cuerda y, si va por debajo, es falta» (Aut.).

${ }^{30}$ Pocos datos nos han llegado de este Pedro de Artiaga, que fue caballero del hábito de Santiago y secretario de Felipe IV.

${ }^{31}$ mesura: «Gravedad, seriedad y compostura de rostro y cuerpo» (Aut.).

${ }^{32}$ Esto... a palacio: omitido (BNE). Correas (2001) recoge refranes muy similares: «Al hombre vergonzoso, el diablo le llevó a palacio», «Al mozo vergonzoso, el diablo lo llevó a palacio» $\mathrm{y}$ «Mozo vergonzoso, el diablo le llevó a palacio: o trajo».

33 estaba dando: acababa de dar (BNE).

${ }^{34}$ pero todo: todo (BNE).

${ }^{35}$ sufrir: Permitir, tolerar, consentir.

${ }^{36}$ Para entender la broma, hay tomar el verbo «limpiar» en la acepción de «hurtar», recogida en Aut., propia del estilo familiar y jocoso. 
Arrugados de escondidos aquí han de ir sin que se queden, que yo sé que se me pueden ${ }^{37}$ fiar papeles molidos ${ }^{* 38}$.

- El molido soy yo - dijo el secretario Carnero*39 muy desazonado*40 de que tenía podrido el hígado ${ }^{41}$.

- Con eso — dije yo-, no hay secretario para más de un día, y no podrá servir más de en sábado*42.

- Sí podrá — dijo ${ }^{43}$ su excelencia—, que es mis pies y mis manos — por cuanto dejara de ganarle con el halago por empeñarle más en la ocupación ${ }^{44}$. Aquí el señor Protonotario*45 se quiso poner tamañito*46 ${ }^{*}$ in tener de qué,

${ }^{37}$ que yo sé que se me pueden: y es cierto que se le pueden (BNE).

${ }^{38}$ Correas (2001) recoge la frase Puédesele fiar oro molido con el significado de «Encarecer la fidelidad de una persona». Que la expresión era bien conocida en la época lo demuestra no sólo la adaptación que aquí se hace, sino también la que encontramos en otro vejamen, este de 1655: «Ese es — dijo el señor Rector- es el señor maestro Juan Martínez Camacho, tan fiel estudiante que no ha tomado cosa del estudio y se le puede fiar filosofía molida, y así estudia en el Romancero general, porque sin escrúpulo puede tomar lo que quisiere» (citado por Madroñal, 2006: 168).

${ }^{39}$ Antonio Carnero y Suárez sirvió en los ejércitos de Flandes como contador principal de ellos desde el año 1585 hasta 1609 y, más tarde, fue contador y veedor de la Artillería y ministro del Consejo de Guerra. Volvió a Madrid casado con doña Bárbara de Santa Cruz, natural de la ciudad de Amberes (Álvarez y Baena, 1789: 129-130). De todos los secretarios del Conde-Duque es el que estuvo más cerca de él y en 1626 fue nombrado ayuda de cámara del rey. Fue secretario de Estado de Castilla y del Despacho Universal. Tras la muerte de Fonseca, Felipe IV lo nombró secretario de Estado de España (Escudero, 1976: 655).

${ }^{40}$ desazonado: «Desapacible, impertinente, colérico y de mala condición»(Aut.).

${ }^{41}$ el hígado: el hígado de trabajar (BNE).

${ }^{42}$ servir más de en sábado: servir en sábado (BNE). Existía la expresión «carne de sábado» que Aut. define así: «Llaman a los extremos, despojos y grosura de los animales comestibles por ser lo que se permite en ese día». La referencia anterior al hígado de Carnero (véase la dilogía entre el apellido del secretario y el animal) y la referencia posterior a «mis pies y mis manos» (carne de casquería) permite la broma, a la vez que juega con la frase hecha Ser sus pies y sus manos «con que se da a entender que alguna persona descansa y alivia a otro en sus dependencias y negociados, de modo que sin él fuera muy dificultoso el despacharlos» (Aut.).

${ }^{43}$ dijo: replicó (BNE).

${ }^{44}$ ganarle con el halago por empeñarle más en la ocupación: ganarle con una lisonja para empeñarle en el trabajo (BNE).

${ }^{45}$ protonotario: «El primero y principal de los notarios y jefe de ellos, o el que despacha con el príncipe y refrenda sus despachos, cédulas y privilegios» (Aut.). Don Jerónimo de Villanueva fue protonotario del Consejo de Aragón desde 1630, secretario del rey, consejero de Estado y miembro del Consejo de Guerra. Hombre de confianza de Olivares, con gran poder y autoridad, no supo hacer frente al problema de Cataluña y se convirtió en el hombre más temido y odiado del Principado. A la caída de Olivares, fue destituido de todos sus cargos y, solo entonces, fue detenido por la Inquisición por su relación con el escándalo de las endemoniadas monjas del convento de San Plácido. Murió en Zaragoza en 1653. (Elliott, 1977; Marañón, 1945).

${ }^{46}$ se quiso poner tamañito: se puso tamañito (BNE). Tamañito: «Temeroso o amedrentado de algún suceso» (Aut.). 
ni con qué ${ }^{47}$, ni para qué, porque es gran ${ }^{48}$ ministro; sin embargo ${ }^{49}$, tiene una falta que no he de decir $^{50}$, pero aquí todos somos de casa, y es que es enemigo de la mitad del género humano, pues dando audiencia a todos, no despacha [a] mujeres ${ }^{* 51}$, y si no lo hiciera de vicio, era gran virtud, pero virtud debe de ser, pues se va arrimando ${ }^{52}$ la misma flaqueza.

- ¿Quién?

- Aquel secretario en los huesos.

- ¡Oh, pecador de mí!, que es don Fernando de Contreras ${ }^{* 53}$, y ese caballero es muy virtuosísimo, y tanto ${ }^{54}$ que en su vida ha tenido más de un antojo, pero bien cumplido, pero $^{55}$ no lo ha podido excusar porque tiene un ojo preñado en una falta $\mathrm{y}$ as $\mathbf{1}^{56}$ por no dar enojo
A la niña de aquel ojo
cuando en la falta repara
por un ojo de la cara
ha de cumplirse el antojo ${ }^{* 57}$.

${ }^{47}$ sin tener de qué, ni con qué: sin saber cómo (BNE).

48 gran: excelente (BNE).

49 sin embargo: pero (BNE).

${ }^{50}$ que no he de decir: que no la querría decir (BNE).

${ }^{51}$ despacha mujeres: despacha a mujeres (BNE). Posiblemente haya alguna alusión a la fundación del convento de monjas de San Plácido que tantos quebraderos de cabeza le produjo, y quizás por eso no quiere despachar o tratar con mujeres.

${ }^{52}$ pues se va arrimando: pues se le arrima a (BNE).

${ }^{53}$ Don Fernando de Fonseca Ruiz de Contreras, caballero del hábito de Santiago, entró al servicio del rey en 1616 y desempeñó importantes funciones en la corte de los Austrias. A él se le confió la Secretaría de Cámara del Consejo de Indias y la del Consejo de Guerra; en 1640 se convirtió en ministro del Consejo de Indias y, en 1648, fue nombrado secretario de Estado de España y del Despacho Universal del Estado, cargos ambos que desempeñaría hasta su muerte en 1660. En 1654 se convirtió en marqués de Lapilla, al contraer nupcias con María Felipa de Fonseca, propietaria del marquesado (Álvarez y Baena, 1789: 51). La extrema delgadez de este secretario lleva a Batres a presentarlo como «la misma flaqueza» o «secretario en los huesos». Sobre su aspecto físico también bromea Rojas en su vejamen de la Academia del 38, pero con una sutileza extraordinaria. Hablando sobre Fonseca dice: «Es una buena cosa y en su vida habló gordo a nadie» (2007: 318). Hablar gordo es una expresión que significa «hablar diciendo fieros y bravatas», pero aquí el secretario no habla gordo a nadie, porque «cada uno habla como quien es», expresión esta última que ya había utilizado el propio Batres al referirse a la gordura de Covarrubias en el vejamen de la Academia del 37 (Academia, 2007: 206).

${ }^{54}$ muy virtuosísimo, y tanto: virtuosísimo, tanto (BNE).

${ }^{55}$ pero bien cumplido, pero: pero ese muy cumplido, mas (BNE).

${ }^{56}$ tiene un ojo preñado en una falta y así: tiene preñado un ojo y ansí (BNE).

${ }^{57}$ No nos ha llegado ninguna imagen de Contreras, si bien se sabe que su amigo personal Diego de Velázquez hizo un retrato de él, hoy desaparecido. Pero parece deducirse que don Fernando llevaría algún parche en el ojo o monóculo; de ahí la referencia a que solo tiene un antojo (léase, anteojo) y el ojo esté preñado, término que define Aut. como «lo que incluye en sí alguna cosa que no se descubre». También Rojas en su Vejamen del 38 hablando de Contreras dice: «Mas ¿que no sabes tú —dijo Mantelillos— por qué se pone antojo 
Atravesaba a sentarse el marqués de Malpica*58, sudando la mayordomía*59 tan gorda y pasando a divertirse al genio de poeta, hizo venta en la costumbre de gran señor y en la de entendido como lo es, cierto ${ }^{60}$, preguntando algunas cosas bien en verdad, y la mejor, la $^{61}$ que preguntó a una dama en esta copla, que decía ${ }^{62}$ :

Juana, de tus ojos sé
que han querido darme enojos ${ }^{63}$,
pero quién si no es tus ojos ${ }^{64}$,
pudiera dármelos, ¿eh?

Estuvo muy bien preguntado aunque fue divertimiento, pero no le sucediera al conde de Puñonrostro*65, que es tan atento caballero que apenas fue su señoría regidor cuando cayó en ello:

Oh, regidor singular,

pues con su oficio cumpliendo,

empezar quiso cayendo

con que no lo pudo errar*66.

delante?». «¿Por qué?», repliqué yo. «Sabrás — prosiguió él— que no lo hace por ser corto de vista, sino para saber mejor, como el antojo es de larga vista, cuántas leguas hace un paso del señor protonotario.» (2007: 318).

${ }^{58}$ Don Baltasar Barroso de Rivera y Enríquez, III marqués de Malpica, I conde de Navalmoral y, desde 1625 por su matrimonio con doña Ana Polonia Manrique de Lara y Luna, conde de Osorno, duque de Galisteo, conde de Morata de Jalón, marqués de Vilueña, mariscal de Castilla, señor de Parla, gentilhombre de la Cámara de Felipe IV, mayordomo de Carlos III, capitán de la Guardia Alemana y caballero de la Orden de Santiago desde 1610. Falleció en marzo de 1669. (Hidalguía, 1979: 584).

${ }^{59}$ La mayordomía del marqués de Malpica ya había sido objeto de burla por parte de Rojas en la Academia de 1637 que se refiere a él como «mayordomo de todas las semanas» (Academia, 2007: 241) y también del vejamen de Coello de 1638: «Vimos pasar al marqués de Malpica, que se daba tanta prisa a ser mayordomo, que parece que se lo han dado por tiempo limitado, porque yo aseguro ha sido él más mayordomo en un año que el conde de Castro en todos los que tiene. Quise hablarle, pero no me conoció, como era de semana, y pasó sin hacer caso.» (Coello, 1964: 319).

${ }^{60}$ señor y en la de entendido como lo es, cierto: señor como lo es, cierto, y en la de entendido (BNE).

${ }^{61}$ la: lo (BNE).

${ }^{62}$ decía: dice (BNE).

${ }^{63}$ que han querido: que procuran (BNE).

${ }^{64}$ sino es: sino (BNE).

${ }^{65}$ En 1638 el V conde de Puñonrostro era don Arias Gonzalo Dávila y Bobadilla (ca. 1598-1661), casado en primeras nupcias con doña Catalina de Acuña y, en segundas, con doña Teresa Pacheco, hija de los condes de Montalbán. En 1622 fue nombrado gentilhombre de la Cámara del cardenal Infante y, más tarde, mayordomo y gentilhombre de Felipe IV, capitán de una compañía de caballos de los hombres de Armas de Castilla. Consiguió el hábito de la Orden de Alcántara en 1631 y acompañó a Felipe IV a Francia para el casamiento de la infanta María Teresa con Luis XIV. (Álvarez y Baena, 1789: 187).

${ }^{66}$ Uno de los tópicos del Siglo de Oro, como se desprende de otros vejámenes y textos en prosa, es que los regidores caen y yerran de continuo. Batres en su vejamen para la 
- ¿Quién es — pregunté- aquel caballero venerable que aunque anciano mueve con escarapelado manejo un bayo ${ }^{* 67}$ ?

Díjome don Juan:

— Este es don fulano Fariñas ${ }^{* 68}$, que, acostumbrado a ejercer con diligencia los puestos que ha ocupado, está haciendo con tanto despejo*69 el oficio de corregidor.

— Por cierto — dije_-, que le hace con tanta facilidad que parece que no hace nada.

\section{A esto dijo don Juan de Espina:}

Es demonio, aunque no tenga

el corregidor qué hacer, dará bien en que entender al corregidor que venga.

$\mathrm{Y}$ vase amontonando mucha gente, pero decía don Juan:

- Ahora saldrá el marqués del Carpio*70 a despejar.

— ¿Qué ha de despejar? — dije_-, que ese caballero es más que capitán de la guardia, capitán de infantería, porque solo trata de hacer gente*71 y de no dejar plaza vaca*72.

Academia del 37 decía: «Empezaron dos poetas la entrada y la erraron, que no siempre la han de errar los señores regidores.» (Academia, 2007: 212); también para esa misma Academia se propuso el siguiente asunto: «Doce quintillas en el estilo de ciego a que dos ermitaños, que también son regidores, ¿en qué caerán primero, en la tentación o en la plaza?» (Academia, 2007: 45); y Rojas en su vejamen para la de 1638 dice: «Todos son unos, señores: /herradores y regidores», jugando con la homofonía de herrar/errar. (2007: 325).

${ }^{67}$ escarapelado manejo un bayo: Escarapelar: «Reñir, trabar cuestiones o disputas y contiendas unos con otros» $(A u t)$. Se ha de interpretar como que se está peleando por controlar el caballo (bayo).

${ }^{68}$ Fernando Ramírez Fariñas fue consejero de Castilla, oidor de Sevilla y Granada, alcalde de Casa y Corte, miembro del Consejo Real, visitador de la Chancillería de Valladolid, capitán General y Alcalde de Sevilla, nombrado por Olivares para el período 1623-1626 (Del Castillo, Castro y Castillo, 1624: 487). Su nombre aparece asociado a la detención de don Rodrigo Calderón; su poco acierto como alcalde y representante de Felipe IV en la ciudad hispalense produjo numerosos descontentos que se materializaron en diversas coplillas que corrían por la ciudad, algunas al parecer erróneamente atribuidas a Francisco de Quevedo (Jauralde Pou, 1999: 281-282).

${ }^{69}$ despejo: «Vale también desenfado, desembarazo, donaire y brío.» (Aut.).

${ }^{70}$ Luis Méndez de Haro (1598-1661), marqués del Carpio, conde de Morente, comendador de la Orden de Alcántara y gentilhombre de la Cámara de su majestad, entre otros muchos títulos, era sobrino del Conde-Duque de Olivares, a quien sucedió en el cargo de valido en 1643. (Elliot, 1991).

${ }^{71}$ hacer gente: «Levantar y reclutar soldados para componer una compañía.» (Aut.). Desde la derrota de la Armada Invencible (1588), el atractivo de la vida militar había disminuido considerablemente y la monarquía tenía serios problemas para formar un ejército estable y fuerte. Ni siquiera las medidas adoptadas por el Conde-Duque en 1632, destinadas a crear una masa militar de amplia base nobiliaria surtieron efecto, y en muchos casos se tuvo que recurrir el reclutamiento forzoso. (Sanz Ayán, 1994; Sánchez Belén, 1994).

${ }^{2}$ vaca: vacía. 
- Pues yo le he visto despejar — dijo.

- ¿A quién —repliqué- ha despejado?

- Al señor de Castrillo*73.

- Eso es engaño, que su señoría siempre fue de la hoja*74, y tan aficionado que por una espada vieja dio una garnacha flamante*75. Por cierto, que es como $^{76}$ una dama hoy.

Dijo don Juan ${ }^{77}$ :

— ¡Qué mala obra me habéis hecho! ${ }^{78}$

- ¿He descompuesto algo?-repliqué.

- No es eso, sino que en mi casa no se puede nombrar cosa que no sea para verla luego, y ahora me he de obligar a enseñar las damas y no damas así como quiere $^{79}$, sino las mucho más ${ }^{80}$ que mujeres y poco ${ }^{81}$ menos que deidades.

$\mathrm{Y}$ corriendo con gran respeto una cortina y con no menor veneración un velo, me enseñó las damas ${ }^{82}$ de palacio, diciéndome:

- Véalas V. m. ${ }^{83}$ todas sin mirarlas, que esto ha de ser ansí ${ }^{84}$.

- Con una basta - le dije ${ }^{85}$ —, pues para quien no lo entiende, a mi parecer $^{86}$, son como los teatinos*87, que en viendo uno están vistos los demás.

- Esto es muy diferente - replicóo ${ }^{88}$ _, pues aunque todas son divinas, lo son por muchos caminos.

${ }^{73}$ Don García de Haro y Avellaneda (1588-1670) heredó el título de conde del Castrillo de su esposa en 1629. En 1624 fue nombrado consejero de Castilla y llegó al Consejo de Estado, convirtiéndose en uno de los personajes más importantes del gobierno de Olivares. En 1632 ocupaba la presidencia del Consejo de Indias y, ocho años después, fue nombrado mayordomo mayor de palacio tras la muerte del V duque de Alba. Entre otros cargos, fue gentilhombre de la Cámara de Felipe IV, de sus consejos de Estado y de Guerra y presidente de Castilla. (Elliott, 1991; Fernández Duro, 1899). Actuó como juez en la academia literaria de 1638.

${ }^{74}$ De la hoja: «Modo vulgar de que usan los espadachines y valentones para decir que alguno es de su gremio.» (Aut.) «Tu donaire es de la hampa, / tu mirar es de la hoja, / tus ojos en matar hombres / son dos Pericos de Soria». (Quevedo, 1971: 335).

${ }^{75}$ ¿Quién es... flamante: omitido (BNE). Garnacha: «Vestidura talar con mangas y una vuelta, que desde los hombros cae a las espaldas. Usan de ella los consejeros y los jueces de las reales audiencias y chancillería.» (Aut.).

${ }^{76}$ que es como una dama hoy: que es una dama (BNE).

77 dijo don Juan: omitido (BNE).

${ }^{78}$ qué mala obra me habéis hecho: «Oh, señor, que mala obra ha hecho vuestra merced», dijo don Juan de Espina (BNE).

79 y no damas así como quiere: y no han de ser damas así como quiera (BNE).

${ }^{80}$ las mucho más: las algo más (BNE).

81 y poco: y muy poco (BNE).

82 damas: señoras damas (BNE).

${ }^{83}$ V. $m$.: omitido (BNE).

${ }^{84}$ ansí: así (BNE).

${ }^{85}$ Con una basta - le dije-: Dije: Con una basta (BNE).

${ }^{86}$ no lo entiende, a mi parecer, son: no las conoce, son (BNE).

${ }^{87}$ teatino: «Se dice de los religiosos regulares de San Cayetano. Tomaron este nombre del obispo de Teati Juan Pedro Carrasa [...] En varios países de España llamaba así el vulgo a los jesuitas.» (Aut.).

${ }^{88}$ replicó: omitido (BNE). 
- Sí, por cierto, pero por el del Pardo, mucho más, porque son bellísimas $^{89}$ por aquel camino y por donde más se celebran, pues están descubiertas desde Pardo a vísperas hasta Carnestolendas puesto el sol.

- Luego por eso ha mandado el conde de la Monclova*90 que se huelguen aunque no sean días de fiesta.

- Sí, señor, que bien sabe su señoría que, siendo mayordomo de semana*91, puede decidir estas cosas como un concilio ${ }^{92}$.

Hacia aquí se quejaba una mujer y no en muy malas endechas, que desde lejos me pareció hermosa como dos mil entendidas, y desde más cerca aseada como otros tantos poetas*93. Doña Ana Caro*94 ${ }^{*}$ será $^{95}$, que entre muchísimos hombres y entre poquísima gana de casarse, se quejaba de su hastío. Yo la aconsejara que si tenía gana de tener muchísima gana de casarse, que se pasara por palacio, porque las mujeres ${ }^{96}$ confirmadas en doncellas de honor se desbautizan por casarse ${ }^{* 97}$, aunque con el nuevo honor tienen ya más mesurada esta maldita inclinación, y si yo me atreviera..., pero con una compa-

${ }^{89}$ porque son bellísimas: que son bellas (BNE).

${ }^{90}$ Don Antonio de Portocarrero y Enríquez de la Vega, caballero de la orden de Santiago y conde de la Monclova, mayordomo mayor de la reina Isabel, esposa de Felipe IV, y del príncipe Baltasar Carlos. Estuvo casado en primeras nupcias con su prima doña Sancha de Mendoza y, tras ser invalidado ese matrimonio, se casó con doña María de Rojas Manrique de Lara. (Burgos, 1859: 141).

${ }^{91}$ mayordomo de semana: Nombre con que se conocía al mayordomo del rey, cargo de gran dignidad, inmediato en grado al de mayordomo mayor. Popularmente se les daba ese nombre porque alternaban por semanas la asistencia continua en palacio.

${ }_{92}$ siendo mayordomo de semana, puede decidir estas cosas como un concilio: puede decidir estas cosas siendo mayordomo de semana como si lo fuera de un concilio (BNE).

${ }^{93}$ Batres arremete duramente contra Ana Caro, que le parece fea como las entendidas y sucia como los poetas. Uno de los asuntos que se desarrollaron en la Academia de 1637 decía: «En diez seguidillas, que a las que tienen mala cara, ¿por qué las socorren luego de bien entendidas, si no hay cosa más necia que ser fea?» (Academia, 2007: 47). «Yo digo que las feas / son entendidas» (Academia, 2007: 190). Era un tópico que belleza y entendimiento no hacía buen maridaje. Por referencias de otros textos, sabemos que la limpieza no era una cualidad de los poetas, que solían ir sucios y desaliñados. La ironía de Batres es evidente.

${ }_{94}$ Ana Caro Mallén de Soto, la décima musa sevillana, como la llamó Vélez en su Diablo Cojuelo, participó en diversas academias literarias, fue autora de diversas composiciones sueltas, de dos piezas dramáticas (Valor, agravio y mujer y El conde Partinuplés), de piezas breves para el Corpus Chisti sevillano entre 1641-1645, y actuó como cronista de diferentes fiestas reales, entre ellas la relación poética de las fiestas religiosas por los mártires de Japón (1628) o la celebrada en 1637, que queda recogida en Contexto de las reales fiestas que se hicieron en el Palacio del Buen Retiro a la coronación de Rey de Romanos y entrada en Madrid de la señora Princesa de Cariñán (Luna, 1993).

${ }^{95}$ será: era (BNE).

${ }^{96}$ mujeres: mondongas (BNE).

${ }^{97}$ El primer asunto de la Academia del 37 rezaba así: «En dieciséis coplas de un romance extirpar la herejía de llamar mondongas a las criadas de las damas, pues no hay cosa más lucida ni de más generoso nombre que servillas, mas y que de aquí adelante se llamen doncellas de honor» (Academia, 2007: 45). Entre los versos de Cáncer: «A bautizarse, señoras, / váyanse ucedes llegando / [...] ¡Agua va! Yo las bautizo.» (Academia, 2007: 109-112). 
ración osaré a decillo: que al cabo han de venir a ser como la gata de Venus ${ }^{* 98}$, que en viendo ${ }^{99}$ un ratón saltó de un estrado, y ansí100 la que una vez fue mondonga, en viendo pasar un marido, se comen las manos tras él ${ }^{101}$.

- Es posible que no se pueda corregir esta bobería.

- Si fuera simplicidad, se pudiera corregir — dijo don Juan—, porque los simples ${ }^{102}$ se corrigen unos con otros.

Mas iba a decir y acabó «con que de muchos simples se hacía un compuesto», pero yo echándole a perder la proposición le dije:

- No es muy cierto que de simples se haga ${ }^{103}$ un compuesto porque don Bernardino de Ayala*104 es compuesto, y no es de simples.

— ¡Qué tiene que ver! — dijo don Juan-. Ese ${ }^{105}$ caballero si como es hombre $^{* 106}$ fuera remedio no pudiera ${ }^{107}$ ser aplicado*108.

— Ni en su vida lo será — dije ${ }^{109}$ —, antes es un perdido*110, pues no teniendo para unas fiestas más de seis toreadores que ponerse, los dio todos de una vez; pues qué diligencias no hizo para regocijar la tarde hasta llegarse a don Gregorio Gallo*111, que dio lanzada*112, y decirle: «Señor don Gregorio,

${ }^{98}$ La gata de Venus: «Por gata muy hermosa, que la pidió un mozo hecha doncella y, estando en el tálamo, corrió tras un ratón. Denota que la natural inclinación nunca se deja» (Correas, 2001.). Batres la compara con la gata porque las damas de palacio se conocían con el nombre de «mondongas» (como se ha señalado en nota anterior) y el mondongo es comida típica de gatos.

${ }^{99}$ viendo: viendo pasar (BNE).

${ }^{100}$ de un estrado, y ansí: del estrado, y así (BNE).

101 pasar un marido, se comen las manos tras él: pasar un novio se come las manos tras él (BNE).

102 no se pueda corregir esta bobería». "Si fuera simplicidad, se pudiera corregir -dijo don Juan-, porque los simples: no se puedan corregir estas boberías». «Sí, pueden, pues son de la calidad de la simplicidad porque los simples (BNE).

103 haga: hace (BNE).

104 Bernardino de Ayala fue conde de Villalba, hijo segundo de don Juan de Ayala, y estuvo casado con doña Francisca de Córdoba y Osorio. Fue caballero de la orden de Calatrava, comendador de Caramuel, comendador del Corral y gentilhombre de la cámara del Cardenal Infante (López de Haro, 1622: 44).

105 ese: que ese (BNE).

106 Ser hombre: «Persona grande en su línea.»(Aut.).

107 pudiera: podía (BNE).

108 aplicarse: Ha de entenderse como «poner una cosa» (poner un remedio a algo) y como «aprovechar el tiempo para adquirir conocimientos», enlazando con la broma anterior sobre la bobería y la simpleza.

109 dije: dije yo (BNE).

110 es un perdido: «Frase que se utiliza para explicar la demasiada franqueza y liberalidad de alguno.» (Aut.).

${ }^{111}$ Gregorio Gallo, caballerizo de su majestad y caballero del hábito de Santiago, destacó como torero en las fiestas reales que solían celebrarse en Madrid. Fue el creador de unas espinilleras que protegían las piernas y que en su honor recibieron el nombre de «gregorianas» (Fernández de Moratín, 1846: 141).

${ }^{112}$ La lidia de toros con lanza era la expresión más genuina del toreo caballeresco y alternaba con la del rejoneo, que era, al parecer, más lucida y gallarda. (Deleito y Piñuela, 1988). 
saque V. m. el caballo alegre con una banda» ${ }^{113}$. Anduvo muy bien aunque temerario porque todo lo quería llevar por punta de lanza*114.

Pero quien anduvo muy en sí fue don Juan Pacheco*115, porque él no solo mataba a los toros con el garrochón*116, como caballero, pero como gran señor, a empellones*117. Y fue mucho no mandar a un lacayo que los matase a palos, pero doblemos los toreadores ${ }^{* 118}$, pues todos los vimos...

- Y dígame V. m. quién[es] son estos dos que vocean.

Y respondió la tácita similitud en el espejo por Diego Suárez*119 y por Carbonel*120,

${ }^{113}$ una vez, pues qué diligencias no hizo para regocijar la tarde hasta llegarse a don Gregorio Gallo, que dio lanzada y decirle: «Señor don Gregorio, saque V. m. el caballo alegre con una banda: una vez, extraño celo de lucir, pues qué diligencia no hizo para regocijar la tarde hasta decille a don Gregorio Gallo: «Saque V. m. el caballo de la lanzada alegre con una banda» (BNE).

${ }^{114}$ A punta de lanza: «Frase adverbial con que se pondera que alguna cosa se lleva con todo el esfuerzo y rigor posible.» (Aut.).

115 Juan Pacheco Ossorio, IV marqués de Cerralbo a partir de 1640, actuó como torero en las fiestas que se celebraron el miércoles, 16 de febrero de ese mismo año. Murió en 1680 sin descendencia. Su prima Leonor heredó el marquesado.

116 garrochón: «Un género de lancilla de vara y media, poco más o menos, con que torean a caballo los caballeros.» (Aut.). No obstante, Deleito y Piñuela señala que el garrochón no era propio de caballeros: «Las armas contra el toro fueron diversas. Las propias del caballero para la lidia eran el rejón, la varilla, la espada y, a veces, la lanza corta. Los peones y lidiadores plebeyos usaban también el garrochón». (1988: 116).

117 a empellones: «Modo adverbial que equivale con violencia, denostada, injuriosa y atropelladamente.» (Aut.).

118 doblemos los toreadores: equivale a dejar cerrado el asunto de los toreadores. Aut. recoge la expresión doblar la llave con el significado de «cerrar». Una expresión similar usó Batres en su vejamen de 1637: «Pero doblemos aquí la loba o arruguémosla, por que no se enoje Coello y prosigamos» (Academia, 2007: 211), con el significado de zanjar un asunto, en aquel caso relacionado con la loba de Coello.

${ }^{119}$ Diego Suárez o Soares, de origen portugués, heredó de su padre, João Alvares Soares, la Secretaria de Finanzas, de la que estuvo al frente entre 1609-1631. Trabajó en estrecha colaboración con el marqués de Castelo Rodrigo. Convertido en hombre de confianza del Conde-Duque y nombrado presidente del Consejo de Portugal y Secretario de Estado, dominó junto con Miguel de Vascocelos, hermano de su primera esposa y tío de la segunda, la política portuguesa desde 1631-1640. Pronto se convirtió en un personaje intrigante y ambicioso, lo que le granjeó severos enfrentamientos con la nobleza. (Schaub, 2001: 149). Diego de Suárez corrió con los gastos de la construcción de la ermita de San Antonio del Retiro, que es a la que aquí se alude.

${ }^{120}$ Alonso Carbonel, arquitecto y escultor, se instaló en la corte a principios del XVII. En 1627 fue nombrado aparejador de las obras del Alcázar de Madrid, del Palacio del Pardo y de la Casa de Campo. En 1633 actuó como maestro mayor de las obras del Buen Retiro y, más tarde, de todas las obras de la Real Casa. Junto con Velázquez, aspiró a ocupar el cargo de aposentador de Palacio, pero no lo consiguió. Murió en 1660. Fue objeto de algunas críticas en la academia de 1637; de hecho, uno de los asuntos decía: «Cuatro octavas en arte mayor, pintando la hermosura y garbo de Carbonel», y Rojas arremete contra su aspecto aceitunado y lo convierte en personaje de su vejamen. Para restañar las heridas, al año siguiente, en la academia de 1638, se escribió un asunto a modo de disculpa: «Dando norabuena a Calero, Covarrubias, Carbonel y Grimaldo de que ya no se burlarán con ellos; 
que después de haber ajustado gastos de ermita, decía Diego Suárez que estaba errada de raíz y echada a perder la planta*121, y Carbonel decía:

\section{- Yo haré otra.}

A lo cual respondió el gran portugués:

- Nao ha de facer, nao.

- Ve aquí V. m. — decía Carbonel—, cómo se han de acertar las cosas; una vez me pide ermita y otras, nao*122.

Departidos $^{* 123}$, el buen Pedro del Yermo*124, aposentador de palacio, que no tiene contra sí más que el apellido, pues no pudiendo acudir [a] algunos encarga que aposenten a todas en su nombre. Y si alguno se queja de haberse quedado en el yermo, da unas voces que es Grimaldo*125. Oille ${ }^{126}$.

Estando en esto ${ }^{127}$, ve aquí donde conocí a Juan Mejía*128, que venía atropellando cuanto entraba ${ }^{129}$ y con una calentura que se le llevaba corriendo de oír decir a otro malo que tenía una calentura como un toro, y cierto que, aun-

pidiendo veinte coplas de un romance» (Bergman, 1975: 560). No obstante, de poco sirvió este asunto, puesto que Rojas vuelve a arremeter contra su fealdad: «Volví a decir, cuando repentinamente se puso delante de los ojos una feísima figura: traía la media cara de Manuel González; la otra media, de Carbonel.» (Rojas, 2007: 315)

${ }^{121}$ Uso dilógico de «planta» como «vegetal» y «plano trazado» que continúa el juego de «echada a perder de raíz», interpretada como «lugar donde la planta se asienta a la tierra» $\mathrm{y}$ «enteramente, desde el principio».

${ }^{122}$ Fácil dilogía de «nao»: «no», en portugués, y «barco».

${ }^{123}$ departidos: separados.

${ }^{124}$ Pedro del Yermo o de Liermo y Herrera era natural de Santander. Fue discípulo del arquitecto Juan Herrera y estuvo al servicio de Felipe II, Felipe III y Felipe IV. Fue ayuda de Cámara, aposentador mayor de Palacio, caballero del hábito de Santiago y perteneció al consejo supremo de la Inquisición. Murió en 1661 (Aramburu-Zabala et alii, 1993: 63; González de Echegaray, 1991: 363).

${ }^{125}$ José Martínez de Grimaldo (1608-1677) estuvo casado con doña Jerónima Sánchez de Cañizares, fue secretario de Felipe IV, al igual que su padre y su hijo, y fue autor y recopilador de poemas religiosos (Piferrer, 1858: 98; Borrego Gutiérrez, 2002: 30). Bien conocidas en la corte eran sus voces. A ellas se dedicó un asunto en la Academia del 1637: «Un romance celebrando qué bien se congoja y qué de buen aire grita Grimaldo y qué primor tiene en no hacer nada.» (Academia, 2007: 45). Batres fue el único que escribió sobre ese tema y se llevó el primer premio. También el propio Batres alude a los gritos de Grimaldo en el vejamen de dicha academia: «Plaza», voceó, que hasta aquí pudo llegar Grimaldo y, estando todo desocupado, sólo su merced ocupó las plazas y nosotros fuimos los oidores de sus gritos.» (Academia, 2007: 219). Y Coello en su vejamen dice que cuando don Juan de Castilla en sueños daba voces «parecía que se le había metido en el cuerpo una legión de Grimaldis.» (1964: 318a).

${ }^{126}$ Pero...oille: omitido (BNE).

${ }^{127}$ Estando en esto: En esto (BNE).

${ }^{128}$ Tenemos pocos datos acerca de este Juan Mejía que es citado varias veces en la Academia burlesca de 1637 y en la de 1638. Aparece entre los caballeros de una de las cuadrillas del Conde-Duque en el desfile con que se iniciaron las fiestas de 1637. En la Academia del 37 obtuvo un primer premio por unas quintillas. En el vejamen de dicha academia, Rojas se refiere a él y a su poca habilidad para con los toros (Academia, 2007: 224-225), y Coello en el vejamen del 38 continúa la misma broma sobre sus artes alanceadoras (1964: 320).

129 entraba: encontraba (BNE). 
que fue hazañería*130, que tuvo mucha gracia, aunque a Luis Vélez*131 no se lo pareció, porque dice (y tiene razón) que no hay hombre tan grandioso $^{132}$ como su barbero, porque, en fin, es hombre que le quita mil canas $* 133134$.

Aquí dijo don Juan de Espina:

- Que me maten si esta noche hubiere fiesta, que he tenido algunos agüeros. Pero yo le dije:

- No he adivinado ${ }^{135}$ nada, porque aún no he tenido mala espina y aún no se ha quebrado el espejo ${ }^{136}$.

Pero en lo que luego vi que decía bien don Juan fue en que todos se iban por no hacer más faltas: los secretarios a trabajar como unos perros, el protonotario a huir de los poetas, los poetas a huir de los certámenes, yo ${ }^{137}$ a pedir a su majestad que me perpetúe esta secretaría con paso*138 para casar una hija, los señores jueces a premiarme ${ }^{139}$ de justicia*140 ya que no los he merecido ${ }^{141}$ de gracia y a pedir a los vejados entre burlas y veras que ${ }^{142}$ tomen esto en burlas, como se ha dicho.

\section{APÉNDICE}

Reproduzco a continuación la intervención de Antonio Hurtado de Mendoza que figura en el manuscrito de la BNE. Sobre el texto no podemos

130 hazañería: «La afectación o aspaviento que se hace con ademanes, dando a entender se escandaliza o escrupuliza alguna cosa, o asusta.» (Aut.).

${ }^{131}$ Luis Vélez de Guevara (1579-1644) estudió Artes y Filosofía. Estuvo un tiempo al servicio del arzobispo de Sevilla, el cardenal Rodrigo de Castro, se alistó y se marchó a Italia con el ejército del conde de Fuentes. A su regreso a España entró al servicio del conde de Saldaña y, más tarde, al del marqués de Peñafiel. Consiguió el cargo de ujier de cámara del rey en 1625 (Álvarez y Baena, 1789: 236). Autor de numerosas comedias en solitario y en colaboración, escribió la sátira social El diablo cojuelo. Actuó como presidente de la Academia de 1637 y en la de 1638, según Bergman (1975: 610).

132 grandioso: gracioso (BNE).

133 Aut. recoge la expresión Quitar canas con el significado de «Frase con que se da a entender el gusto que recibe uno con alguna cosa agradable». No obstante, aquí se alude también a la avanzada edad de Vélez.

${ }^{134}$ Aquí se añade el fragmento de vejamen de don Antonio Hurtado de Mendoza que aparece en el apéndice.

135 dije: «No he adivinado»: dije que no había adivinado

${ }^{136}$ porque aún no he tenido mala espina y aún no se ha quebrado el espejo: porque había tenido mala espina ni se había quebrado el espejo (BNE).

${ }_{137}^{137}$ poetas; los poetas a huir de los certámenes; yo: poetas; yo (BNE).

${ }^{138}$ paso: «Licencia o facultad de transferir a otro la gracia, merced empleo o dignidad que se ha concedido a alguno o posee» (Aut.).

139 premiarme: darme un premio (BNE).

${ }^{140}$ de justicia: «Modo adverbial que vale debidamente, conforme a justicia y razón» (Aut.).

${ }^{141}$ no los he merecido: no le merezco (BNE).

${ }^{142}$ vejados entre burlas y veras que tomen: vejados que entre burlas y veras tomen (BNE). 
apuntar más que hipótesis. Posiblemente se trate de un fragmento de algún vejamen que escribiera para la academia del 38, pues la extensión es demasiado breve para ser un texto completo y una intervención de tales características, incrustada en un vejamen principal, no suele ser común. Además, desde el punto de vista temático no guarda ninguna relación con el escrito de Batres, mientras que resulta evidente su conexión con la academia de 1638, pues los vejaminados actuaron como jueces del certamen poético. Si realmente se confirma que se trata de un texto fragmentario, deberíamos ampliar el número de vejámenes que se leyeron en el Salón de Reinos el 11 de febrero de 1638, pues al de Rojas, Batres y Coello habría que añadir el de Hurtado de Mendoza.

\section{Texto}

\section{Prosiguió don Antonio de Mendoza}

En esto se oyó una tempestad murmuradora como si viviera cerca algún hombre de bien y poderoso, y era una furia de poetas que blasfemaba de los jueces del certamen, teniendo cada uno en esto la mucha y buena razón que en todo, y decían:

- Sacaron la gente de provecho y metieron unos discretos estípticos que no saben digerir un consonante confite y quitáronnos ¿a quién? Por lo menos al conde de la Monclova ${ }^{143}$, gran caballero de gran estómago y talento, de gran valor y sangre y que por ambas líneas le tocaba ser juez perpetuo de las coplas, que por el valentísimo Luis Fernández Portocarrero desciende de toda la vega de Granada, y por el esclarecido Garcilaso son escuderos de su casa cuantos versificantes hay en el mundo.

Atendió el conde a la queja, que estaba en el cuarto de la camarera mayor a preguntalle si las damas podían estornudar en público, y exclamó:

- Tate, tate, el don cuellecito Antonio ${ }^{144}$ me ha hecho esta bellaquería, que, sabiendo que conmigo no valen favores, me hizo excluir y poner en mi lugar a un gran pariente del grande de su amo; gran cosa haberse criado un hombre en el bureo, que no se teme la entereza de otro tribunal.

Y volviéndose a los quejosos les dijo (cierto, con ternura y ponderación y muy despacio):

\footnotetext{
${ }^{143}$ Como se ha señalado en nota anterior, el conde de la Monclava en 1638 era Antonio Portocarrero de la Vega, que, como se indica en este vejamen, era nieto de Luis Fernández Portocarrero (comendador de Azuaga, caballero de la orden de Santiago, señor de Almenara y Fuente del Álamo y primer conde de Palma) y de su segunda esposa, doña Leonor de la Vega, hermana del poeta Garcilaso (Burgos, 1859: 141).

${ }^{144}$ Nombre con que se conocía jocosamente a don Antonio Coello, que estaba a las órdenes de don Francisco IV Fernández de la Cueva y Enríquez de Cabrera, VIII duque de Alburquerque.
} 
- Amigos, igualmente habéis mirado por mi honra y por vuestra justicia. Yo escribiré al conde de Palma, mi tío, la falta que os he hecho ${ }^{145}$.

Apenas lo escuchó don Gaspar Bonifaz, que junto con ser excelente cortesano no es tan modesto que a pocos abuelos no tope en Castilla con un almirante, y con saña les replicó:

- Menguados, si a mí me excluyeron que soy tan buena pareja para un desagravio como para la plaza, ¿en qué quedó ofendido ningún conde?

Y respondieron:

- Señor, a su señoría lloramos, que como los versos son pies y vuesa merced es apasionado de ellos, no nos hizo tanto perjuicio ${ }^{146}$.

- Bergantes — añadió el caballero-, dejad esa frialdad, que voto a Dios que cuando en los pies se usaran otras cabelleras que los zapatos, los dejara tan de par en par como la cabeza, y por dicha de garrochón y espada en fuera tan garbosas son mis manos que todo lo han de padecer mis pies.

Apartáronse de tan justo enojo, pero no de la querella de los jueces, y prosiguieron diciendo:

- Gracioso donaire que nos traigan para juzgarnos a dos grandísimos virreyes del otro mundo, y ¿qué gente somos los verseros que hemos menester tan autorizados fiscales?

- De Esquilache ${ }^{147}$, el príncipe, ya sabemos que lo es de la poesía y aun rey de la música, mas para tener tantos papas en su linaje muy cortas indulgencias concede a los versos. Baste que castigue tanto los suyos para querellos después tan justa y tiernamente, sea piadoso con los ajenos, y sóbrele, que no hay más que culpalle que no saber sufrir culpas.

Y otro decía:

— iQuién diablos nos metió en la judicatura del gracejo y del chiste al venerable Beda, el más que ilustre marqués de Cerralbo ${ }^{148}$, que si en México fue tan

${ }^{145}$ El conde de la Monclova se refiere a su tío don Luis Fernández de Portocarrero, II conde de Palma, primogénito del comendador de Azuaga.

${ }^{146}$ Una de las chanzas constantes que aparece en diversos vejámenes es el tamaño de los pies de Gaspar de Bonifaz, lo que permite la broma de los versos con sus pies métricos. En el vejamen de Coello de ese mismo año, 1638, se lee: «-[...] Digan lo que dijeren, no le pueden negar que es gran hombre de plaza, aunque he oído decir que los toros no temen tanto que les ponga la mano como que les ponga el pie». Y oyendo, esto don Gaspar, se levantó de donde estaba y dijo: - Téngase V. m., y no me ponga apodos a los pies, y me vendrán chicos por grandes que sean. Y para otra vez oiga estos que están hechos en mi horma y me vendrán mejor.» (1964: 319).

${ }^{147}$ Francisco de Borja y Aragón (1581-1658) nació en Italia y adquirió el título de Príncipe de Esquilache al casarse con doña Ana de Borja. Desempeñó el cargo de virrey del Perú entre 1615 y 1621. Fundó la Academia Antártica Limeña y el Coliseo de Comedias en Potosí. Sus inclinaciones literarias lo llevaron a publicar a su regreso a España, en 1621, sus poemas, entre los que destacan Nuestro Señor Jesucristo (1638), Obras en verso (1648) y Nápoles recuperada por el rey don Alfonso (1631). En la Academia de 1637 actuó como juez del certamen literario.

${ }^{148}$ El marqués de Cerralbo era don Rodrigo Pacheco y Osorio (1580-1640), nombrado XV virrey de la Nueva España entre noviembre de 1634 y septiembre de 1635. 
acertado, admirable y prudente virrey, piense pesia tal que ha hallado en Castilla otra nueva España de ingenios; y que ya no viven aquellos floridísimos de su tiempo, cuando el suyo entre todos se descollaba más por grande que por alto y, si no teme el haberse opuesto a los poetas, crea que no tendrá menos que hacer en resistillos que su padre famoso en defender a la Coruña del Draque ${ }^{149}$. Y si ayer su gallardo hijo dejó la admiración en negro, no ha sido buen ejemplar el dejar hoy a las musas en blanco. ${ }^{150}$

Y al señor don Luis de Haro le pareció demasía el sentimiento de estos hombres porque a su juicio, aunque el tomar por asesor al conde de Castrillo no pudiera dar más justificadas las sentencias, aunque para entero y justo, otro tío le hiciera más frecuente el ejemplo. Pero los lidiadores del certamen gritaban mostrando que no hay cosa más perjudicial que meter a mozos de demasiada cordura en materias serias y graves, que por acreditarse de rectillos condenarían a la inocencia del mismo don Francisco Zapata.

Al marqués Malvezzi ${ }^{151}$ no se atrevían a mormuralle conociendo que, como persona tan entendida y de tan ilustres partes, no haría voto por juez moderno. Si bien en saber de todo, ninguno tanto, y esa culpa echaban al gran ingenio de Francisco de Rioja ${ }^{152}$, que les pareció que su autoridad arrastraría aquel compañero, y baldonábanle diciendo:

- ¿Qué se nos da a nosotros que sea tan docto, expedito y eminente en todas lenguas, si una sola que tiene es tan ruda? ${ }^{153}$

${ }^{149}$ Referencia a don Juan Pacheco de Toledo, gobernador de la ciudad de La Coruña, que tuvo que hacer frente, entre el 4 y el 19 de mayo de 1589, a la Armada invencible inglesa o Contraarmada, enviada por Isabel I de Inglaterra y capitaneada por el almirante Sir Francis Drake. El objetivo de la reina era aprovechar la superioridad que había conseguido al derrotar a la Armada invencible de Felipe II y acabar con los pocos barcos sobrevivientes que se reparaban en los astilleros de la Coruña, San Sebastián y Santander. Sus planes, más ambiciosos, la llevaron a anhelar la conquista de Portugal y dominar el punto estratégico de las Azores.

${ }^{150}$ El jesuita Sebastián González, al describir la celebración del día anterior al que se refiere Mendoza, señala: «D. Juan Pacheco, heredero del marqués de Cerralbo, vestido de luto, caballo negro, 24 negros por lacayos vestidos de luto. La causa dicen es por estar desfavorecido de la hija del marqués de Cadraita (Caldereita), con quien pretende casarse, y haberse retirado esta señora de favorecerle por no querer su padre case con él». (Memorial Histórico Español, 1862: 328). Tal vez a la oscuridad de su traje se refiera el vejador al decir que había dejado «la admiración en negro».

${ }^{151}$ Virgilio Malvezzi (1595-1653), soldado, ensayista y diplomático italiano de familia noble, fue introducido en la corte de Felipe IV por el Conde-Duque de Olivares y nombrado consejero de Estado y de la Guerra (1636), cronista oficial de la corte (1638), embajador en Londres y asesor del Cardenal-Infante Fernando de Austria (1641-1643).

${ }^{152}$ Francisco de Rioja (1583-1659). Se graduó en Leyes y estuvo bajo la protección del Conde-Duque de Olivares, que lo nombró bibliotecario y abogado consultor. Sufrió prisión por ser autor de unas injuriosas letrillas satíricas que circularon por la corte. Se retiró a Sevilla y regresó a Madrid en 1654. Es autor de numerosas composiciones poéticas, cartas y alegatos. Participó en la academia burlesca de 1637 como juez del certamen.

${ }^{153}$ Batres ya había bromeado sobre los problemas articulatorios de Francisco de Rioja en su vejamen para la Academia de 1637: «Y encajándose el sombrero el gran sobrino como para 
Y don Francisco de Calatayud ${ }^{154}$, no menos noble caballero que insigne secretario, decía:

- Terrible cosa, que pudiendo hacerme el conde mi señor leonero del Retiro, me haya hecho juez de más erizados animales, que para la justificación del caso antes de venir a dar mi parecer estudié muchas horas en todos los poetas latinos que tratan de academias burlescas protonotarías, y en mi voto me conformé con los mejores textos y con las peores testas. Pero dura esclavitud tratar con legos.

Y pensando don Antonio de Mendoza que lo decía por él, replicó ${ }^{155}$ :

- Señor don Francisco, yo no soy más de uno, pero forrado en pulidísima lisonja.

- Eso es la verdad — respondió un poeta-, pero si V. m. ha condenado a los que quedamos sin premio, juro a Dios que se casa mejor que juzga y que a V. m. de aquí adelante le fío yo mi boda pero no mi copla y, antes de que V. m. entrase en palacio, gran persona solía ser por la suya, aunque estaba ya remotillo con los grandes negocios que no tiene, y pues en V. m. solo se olvidaron los méritos de su achaque y costumbre para premiar un ingenio, ya más quisiera olivares que laureles.

Dijo y prosiguió Batres.

\section{BIBLIOGRAFÍA CITADA}

Academia burlesca que se hizo en Buen Retiro a la majestad de Filipo Cuarto el Grande. Año de 1637 (2007), Teresa Julio (ed.). Madrid-Frankfurt: Iberoamericana-Vervuert.

Álvarez y Baena, José Antonio (1789). Hijos de Madrid, ilustres en santidad, dignidades, armas, ciencias y artes. Diccionario Histórico. I. Madrid: Oficina de D. Benito Cano.

Aracil, Alfredo (1998). Juego y artificio: autómatas y otras ficciones en la cultura del Renacimiento a la Ilustración. Madrid: Cátedra.

Aramburu-Zabala, Miguel Àngel et alii (1993). «Pedro de Liermo en Montecorbán», Juan de Herrera y su influencia. Santander: Universidad de Cantabria.

réplica de conclusiones de la compañía, le detuvo Francisco de Rioja, insigne por tantas partes, virtudes y letras, pero ¡ay de la $P$ y la $R$ en sus labios!, en quien no peligra otra cosa humana, aunque si se encoleriza en griego, ¡ay del mismo Virgilio!» (Academia, 2007: 222).

${ }^{154}$ Francisco López de Calatayud, hombre de armas y letras, de origen sevillano, fue nombrado secretario de Felipe IV en noviembre de 1621 a instancias del Conde-Duque de Olivares, que se rodeó de una camarilla de adeptos para llevar a cabo su programa de reformas. Calatayud, hombre asiduo a las fiestas cortesanas, actuó como juez de la academia burlesca de 1637.

${ }^{155}$ Antonio de Mendoza se da por aludido porque Góngora siempre se refería a él como el «aseado lego» e insistía en que era «poco adornado de estudios» (La Barrera, 1968). A esa misma broma había hecho referencia Batres en su vejamen del año anterior. "Y don Antonio de Mendoza quiso acusar luego la civilidad del concepto, pero como se hablaba en latín, metiose dentro de su romance, que aunque de gran primor, en fin es ratón de una sola lengua, pero si se congoja de lego chico, pásese al ingenio y quedará grande.» (Academia, 2007: 222-223). 
Bergman, Hannah E. (1975). «El Juicio final de todos los poetas muertos y vivos (Ms. inédito) y el certamen poético de 1638», Boletín de la Real Academia Española. 55, pp. 551-610.

Borrego Gutiérrez, Esther (2002). Un poeta cómico en la corte: vida y obra de Vicente Suárez de Deza. Kassel: Reichenberger.

Brown, Kenneth (1980). Anastasio Pantaleón de la Ribera. Madrid: José Porrúa Turranzas, S.A. Ediciones.

Brown, Kenneth (1993). «Aproximación a una teoría del vejamen de academia en castellano y catalán en los siglos XVII y XVIII: de las Academias españolas a la Enciclopedia francesa», en Evangelina Rodríguez Cuadros (ed.), De las Academias a la Enciclopedia: El discurso del saber en la modernidad. Valencia: Alfons el Magnànim, pp. 225262.

Burgos, Augusto de (1859). «Condes de la Monclova». Blasón de España: libro de oro de su nobleza. Madrid: Imprenta y estereotipia de M. Rivadeneira. Vol. IV.

Carrasco Urgoiti, M. Soledad (1965). «Notas sobre el vejamen de Academia en la segunda mitad del XVII», Revista Hispánica Moderna. 41, pp. 97-111.

Coello, Antonio (1964). «Vejamen que se dio en el certamen del Buen Retiro, año 1638», en Antonio Paz y Melia (ed.), Sales españolas o agudezas del ingenio nacional. BAE. Vol. CLXXVI. Madrid: Ediciones Atlas, pp. 317-321.

Correas, Gonzalo (2001). Vocabulario de refranes y frases proverbiales. Rafael Zafra (ed.). Pamplona-Kassel: Universidad de Pamplona-Edition Reichenberger.

Del Castillo, Julián; Castro y Castillo, Jerónimo (1624). Historia de los reyes godos que vinieron de la Sitia de Europa contra el imperio romano y a España con sucesión de ellos hasta los Reyes Católicos. Madrid: Luis Sánchez.

Deleito y Piñuela, José (1988). También el pueblo se divierte. Madrid: Alianza.

Egido, Aurora (1984). «Una introducción a la poesía y a las academias literarias del Siglo de Oro», Estudios Humanísticos. VI, pp. 9-26.

Egido, Aurora (1990). «Floresta de vejámenes universitarios granadinos» (siglos XVIIXVIII), Bulletin Hispanique. 92, pp. 309-332.

Egido, Aurora. «De ludo vitando. Gallos áulicos en la Universidad de Salamanca». El Crotalón. Anuario de Filología, 1984. 1, pp. 609-648.

Elliott, J. H. (1977). La rebelión de los catalanes: un estudio sobre la decadencia en España: 1598-1640. Madrid: Siglo XXI.

Elliot, J. H. (1991). El Conde-Duque de Olivares. Barcelona: Crítica.

Escudero, José Antonio (1976). Los secretarios de Estado y Despacho, 1474-1724. Madrid: Instituto de Estudios Administrativos, III.

Fernández de Avellaneda, Alonso (2005). El ingenioso hidalgo don Quijote de la Mancha. F. García Salinero (ed.). Madrid: Castalia.

Fernández de Moratín, Nicolás y Leandro (1846). «Origen y progresos de las fiestas de toros», en Obras de don Nicolás y don Leandro Fernández de Moratín. II. BAE. Madrid: Atlas.

Fernández Duro, Cesáreo (1899). «Testamento de don García de Avellaneda y Haro», Boletín de la Real Academia de la Historia. 34, pp. 154-157.

González de Echegaray, M. del Carmen (1991). Artistas Cántabros de la Edad Moderna. Santander: Universidad de Cantabria.

González Maya, Juan Carlos (2006). «Vejamen de don Jerónimo de Cáncer. Estudio, edición crítica y notas», Criticón. 96, pp. 87-114.

Hidalguía, Revista de genealogía, nobleza y armas (1979). 154-155.

Hidalguía. Revista de genealogía, nobleza y armas (1980). 159-163.

Hurtado de Mendoza, Antonio (1947). «En un convite que hizo a los secretarios del Conde-Duque de Olivares», en Obras poéticas. Rafael Benítez Claros (ed.). I. Madrid: Gráficas Ultra S. A. 
Jauralde Pou, Pablo (1999). Francisco de Quevedo (1580-1645). Madrid: Castalia.

Julio, Teresa (2007). «El vejamen de Rojas para la Academia de 1638. Estudio y edición», Revista de Literatura. LXIX, 137, pp. 299-332.

King, W. F. (1963). Prosa novelística y academias del Siglo de Oro. Madrid: BRAE, Anejo $\mathrm{X}$.

La Barrera y Leirado, Cayetano A. (1968). Catálogo bibliográfico y biográfico del teatro antiguo español. London: Tamesis Book Ltd.

López de Haro, Alonso (1622). Nobiliario Genealógico de los reyes y títulos de España. Madrid: Luis Sánchez.

Luna, Lola (1993). Introducción a Valor, agravio y mujer. Madrid: Castalia, 1993.

Madroñal, Abraham (2005). De grado y de gracias. Vejámenes universitarios de los Siglos de Oro. Madrid: CSIC.

Madroñal, Abraham (2006). «Razones de la risa en el claustro (Los procedimientos humorísticos en los vejámenes de grado)», en Ignacio Arellano y Victoriano Roncero (eds.), Demócrito Áureo. Los códigos de la risa en el Siglo de Oro. Sevilla: Renacimiento, pp. 143-178.

Madroñal, Abraham (2009). «Entremeses y fiesta pública en el Madrid del siglo XVII», en José María Díez Borque (ed.), Literatura, política y fiesta en el Madrid de los Siglos de Oro. Madrid: Visor, pp. 289-334.

Marañón, Gregorio (1945). El Conde duque de Olivares. La pasión de mandar. Madrid: Espasa-Calpe. Memorial Histórico Español (1862). XIV. Madrid: Imprenta Nacional.

Orozco, Juan (1964). «Vejamen que dio Juan de Orozco en casa del contador Agustín Galarza», en Antonio Paz y Melia (ed.), Sales españolas o agudezas del ingenio nacional. BAE. CLXXVI. Madrid: Ediciones Atlas, pp. 325-331.

Pérez de Montalbán, Juan (1632). Para todos. Ejemplos morales, humanos y divinos en que se tratan diversas ciencias, materias y facultades. Alonso Pérez: Imprenta del reino.

Piferrer, Francisco (1858). Nobiliario de los reinos y señoríos de España. A. Rújula y Busel (ed.). Madrid: Imp. De M. Minnesa.

Quevedo, Francisco de (1971). Jácaras. José M. Blecua (ed.). Madrid: Castalia.

Raneo, José (1853). «Libro donde se trata de los virreyes terratenientes del reino de Nápoles», en M. Salvá (ed.), Colección de documentos inéditos para la historia de España. Madrid: Imprenta de la Vda. de Calero, pp. 524-525.

Rojas Zorrilla, Francisco de (2007). «Vejamen», en Teresa Julio (ed.), «El vejamen de Rojas para la Academia de 1638. Estudio y edición», Revista de Literatura. LXIX, 137, pp. 299-332

Romera Navarro, M. (1941) «Querellas y rivalidades en las Academias del siglo XVII», Hispanic Review. 9, pp. 494-499.

Saavedra, Ángel (2007). Estudio histórico de la sublevación de Nápoles capitaneada por Masianelo con sus antecedentes y consecuencias hasta el restablecimiento del gobierno español. Madrid: Sucesores de Hernando, 1917 (reed. Linkgua: Barcelona).

Sánchez Belén, Juan Antonio (1994). «Colonos y militares: Dos alternativas de promoción social», en J. N. Alcalá-Zamora (coord.), La vida cotidiana en la España de Velázquez. Madrid: Ediciones Temas de Hoy, pp. 279-304.

Sánchez, José (1965). Academias literarias del Siglo de Oro. Madrid: Gredos.

Sánchez, Vicente (2003). «Vejamen que se leyó en una academia en casa del excelentísimo señor duque de Ciudad Real, príncipe de Esquilache, virrey y capitán general del Reino de Aragón», en J. Duce García, Zaragoza (ed.), Lira poética. I. Zaragoza: Prensas Universitarias de Zaragoza, pp. 85-116.

Sanz Ayán, Carmen (1994). «Poderosos y privilegiados», en J. N. Alcalá-Zamora (coord.), La vida cotidiana en la España de Velázquez. Madrid: Ediciones Temas de Hoy, pp. 149167. 
Schaub, Jean Frédéric (2001). Le Portugal au temps du conde-duc d'Olivares (1621-1640). Madrid: Casa Velázquez.

Vélez de Guevara, Luis (1902). El diablo Cojuelo. Adolfo Bonilla y San Martín (ed.). Vigo: Tip. Eugenio Krapf, pp. 253-262.

Fecha de recepción: 7 de junio de 2010

Fecha de aceptación: 19 de enero de 2011 